\title{
TÖBBDIMENZIÓS ÉGHAJLATI IDŐSOROK EXTRÉMUMAINAK VIZSGÁLATA
}

\author{
Izsák Beatrix $^{(1)(2)(D)}$, Szentimrey Tamás ${ }^{(3)}$, Pongrácz Rita ${ }^{(1)}$ (D), Lakatos Mónika ${ }^{(2)}$ (D) \\ ${ }^{(1)}$ ELTE Meteorológiai Tanszék, 1117 Budapest, Pázmány Péter sétány 1/A \\ (2) OMSZ Elörejelzési és Éghajlati Osztály, 1024 Budapest, Kitaibel P. u 1. \\ (3) Varimax Bt., 1039 Budapest, Nyár u. 11. \\ e-mail: izsak.b@met.hu
}

\section{Bevezetés}

Az éghajlatváltozás tanulmányozásához elengedhetetlen a szélsőségek vizsgálata. A szélsőségek vizsgálata történhet egyrészt úgy, hogy az extrém éghajlati események idősorát vizsgáljuk, másrészt úgy, hogy az éghajlati idősorok extrémumait vizsgáljuk. Ez utóbbi esetben, ha egyetlen elemet vizsgálunk, a szélsőség az adott idősor maximuma vagy minimuma. Jelen tanulmányban az éghajlati idősorok szélsőértékeit határozzuk meg úgy, hogy több meteorológiai elemet együttesen vizsgálunk és így határozzuk meg az extrémumokat. Rögtön felmerül a kérdés, hogy többdimenziós idősornál van-e értelme szélsőértékről beszélni, és ha igen, milyen módon határozható meg. Ehhez kapcsolódóan bemutatjuk az ún. norma módszert, definiáljuk a vektorváltozó extrémumát, és példákon keresztül mutatjuk be a módszer alkalmazását csapadék- és hőmérséklet-idősorok együttes vizsgálatával. Tanulmányunkhoz a magyarországi napi átlaghőmérsékleti és csapadék idősorokat használtuk fel az 1901-2019 időszakra. Az alábbiakban bemutatjuk az együttes vizsgálat során kapott legfontosabb eredményeket, és összevetjük az egydimenziós esetben kapott szélsőségekkel. Amennyiben ezzel a módszerrel visszakapjuk az eredeti egydimenziós idősorok szélsőségeit, úgy az éghajlatváltozás vizsgálatához nem ad többletet a bemutatni kívánt módszer. Elöljáróban összegezhetjük, hogy elemzéseink azt jelzik, hogy vannak olyan évek, amelyek csak a csapadék vagy csak az átlaghőmérséklet szempontjából nem számítanak extrémnek, de együtt vizsgálva a két elemet mégis kimondhatjuk, hogy szélsőséges évek voltak. Ezek alapján tehát a többdimenziós éghajlati idősorok extrémumainak vizsgálata kiegészíti, és ezáltal hatékonyabbá teszi az éghajlatváltozás vizsgálatát ahhoz képest, mintha csak az egydimenziós idősorokat vizsgálnánk.

\section{Adatok}

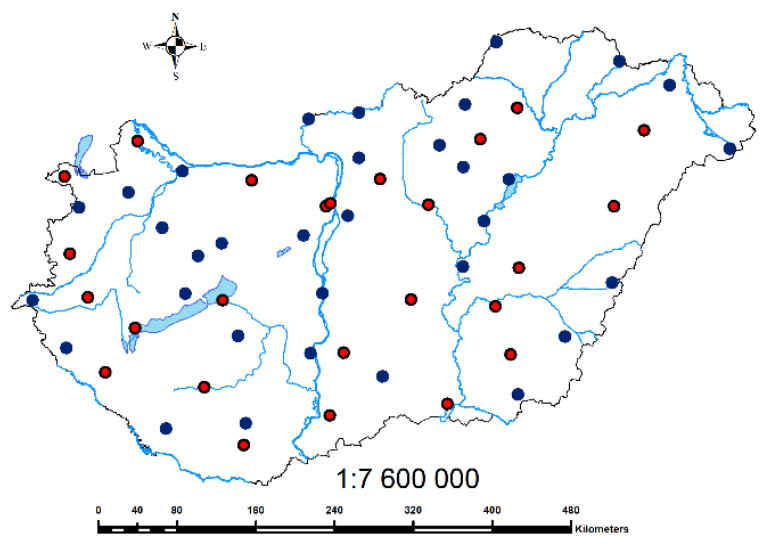

1.ábra: Hőmérsékletmérő állomások

$($ 1971-2019, 1901-2019)

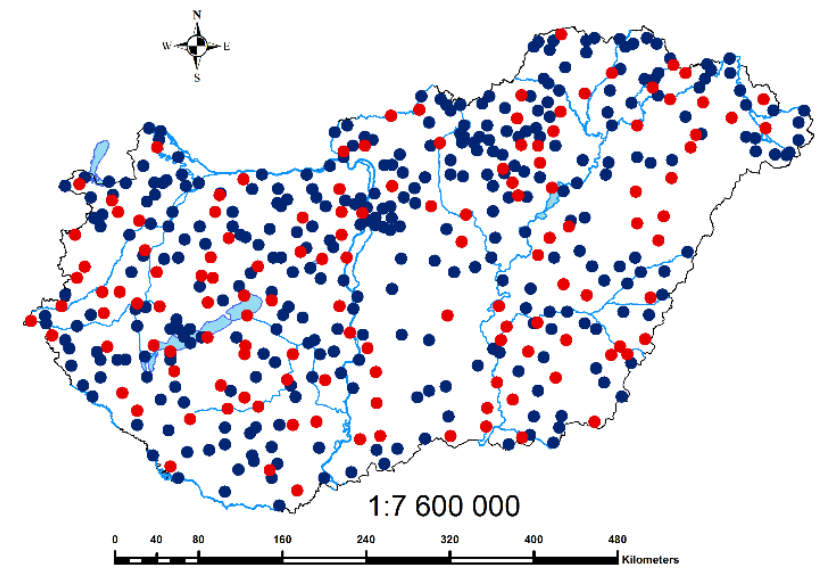

2. ábra: Csapadékmérő állomások

$(\bigcirc 1951-2019, \bullet 1901-2019)$ 
Tanulmányunkhoz az elmúlt 119 év napi adatait használtuk fel. Ez hőmérséklet esetén 1901. január 1. és 2019. december 31. között 25 állomás adatait jelenti, míg az 1971. január 1-től a 2019. december 31-ig terjedő időszakra

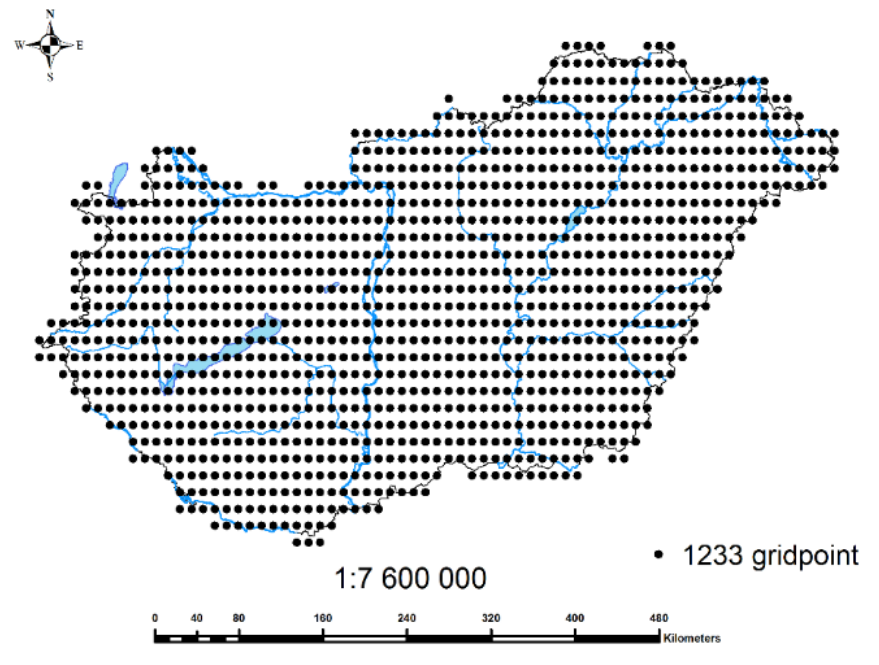

3. ábra: A rácspontok elhelyezkedése. további 33, azaz összesen 58 állomás adatait vettük figyelembe. Csapadék esetén 1901. január 1-2019. december 31. időszakban 131 állomás, míg 1951. január 1-től 2019. december 31-ig további 330 csapadékmérő állomás adataival számoltunk, tehát erre a rövidebb időszakra 461 állomás állt rendelkezésünkre (1. ábra és 2. ábra).

Első lépésben a nyers mérésekből elő kellett állítani reprezentatív idősorokat. Ugyanis az éghajlati, különösen az éghajlat változásával kapcsolatos vizsgálatokhoz hosszú, jó minőségü, ellenőrzött, térben és időben egyaránt reprezentatív adatsorok szükségesek (Izsák \& Szentimrey, 2020). A változó mérési körülmények, például állomás áthelyezés, a mérési idő megváltozása vagy müszercsere inhomogenitást, indokolatlan törést eredményezhetnek az idősorokban. Az esetleges adathibák és inhomogenitások kiszürését, korrekcióját és az adathiányok pótlását a MASH (Szentimrey, 2014) homogenizációs eljárás alkalmazásával végezzük. Az országos rácsponti átlagok idősorait pedig a MISH (Szentimrey \& Bihari, 2014) módszerrel állítjuk elő, ily módon az adatoknak egy jó minőségű, reprezentatív rendszeréhez jutunk. A rácspontok rendszere a 3. ábrán látható.

\section{Többdimenziós idősorok extrémumainak vizsgálata: általános eset}

Többdimenziós idősor:

$\mathbf{X}(\mathrm{t})=\left[X_{1}(t), X_{2}(t), \ldots, X_{N}(t)\right]^{\mathrm{T}}$

$(\mathrm{t}=1,2, \ldots, \mathrm{n})$

független azonos eloszlású valószínúségi vektorváltozók.

A komponensek eloszlásfüggvényei: $\mathrm{F}_{\mathrm{j}}(\mathrm{x})$

$$
\begin{aligned}
& (j=1,2, \ldots, N) \\
& (t=1,2, \ldots, n) \\
& (t=1,2, \ldots, n)
\end{aligned}
$$$$
\text { Varható értékek vektora: }
$$$$
\mathrm{E}(\mathbf{X}(\mathrm{t}))=\mathrm{m}=\left[\mathrm{m}_{1}, \mathrm{~m}_{2}, \ldots, \mathrm{m}_{\mathrm{N}}\right]^{\mathrm{T}}
$$

Szórások vektora:

$\mathrm{D}(\mathbf{X}(\mathrm{t}))=\mathrm{D}=\left[\mathrm{D}_{1}, \mathrm{D}_{2}, \ldots, \mathrm{D}_{\mathrm{N}}\right]^{\mathrm{T}}$

Ahhoz, hogy a vektorváltozó vizsgálatának során egyik komponens se legyen domináns, azonos eloszlásúra transzformáljuk az egyes komponenseket. Jelen esetben az azonos eloszlásnak a standard normális eloszlást választottuk Szentimrey (1999) alapján.

Legyenek a meteorológiai változók az adott időszakban:

$X_{j}(t)$

$$
\begin{aligned}
& (j=1, \ldots, N ; t=1,2, \ldots, n), \\
& (j=1, \ldots, N ; t=1,2, \ldots, n),
\end{aligned}
$$

a standard normális sorok:

$Z_{j}(t)=\Phi^{-1}\left(F_{j}\left(X_{j}(t)\right)\right) \in N(0,1)$

ahol $F_{j}(x)$ az $X_{j}(t)$ eloszlásfüggvénye, $\Phi^{-1}$ a standard normális eloszlásfüggvény inverze. 


\section{Legyen}

$\mathbf{Z}(\mathrm{t})=\left[Z_{1}(\mathrm{t}), \ldots, Z_{N}(\mathrm{t})\right]^{T}$

a vizsgált vektorváltozó, immáron transzformált komponensekkel.

Ekkor az együttes extrém index:

$$
\|\mathbf{Z}(\mathrm{t})\|_{\mathbf{R}^{-1}}=\sqrt{\mathbf{Z}(\mathrm{t})^{T} \mathbf{R}^{-1} \mathbf{Z}(\mathrm{t})} \quad(\mathrm{t}=1,2, \ldots, \mathrm{n})
$$

ahol $\mathbf{R}$ a $\mathbf{Z}(\mathrm{t})$ korreláció mátrixa.

A fenti norma alapján:

$$
\mathbf{Z}(\mathrm{e}) \text { extrém, ha }\|\mathbf{Z}(\mathrm{e})\|_{\mathbf{R}^{-1}}=\max _{1 \leq t \leq n}\|\mathbf{Z}(\mathrm{t})\|_{\mathbf{R}^{-1}} \quad(\mathrm{t}=1,2, \ldots, \mathrm{n})
$$

A vizsgálat célja, hogy az elemek azonos eloszlására vonatkozó nullhipotézis teljesül-e, azaz megvizsgáljuk, hogy $\|\mathbf{Z}(\mathrm{e})\|_{\mathbf{R}^{-1}} \leq \alpha$ teljesül-e (ahol $\alpha$ az adott szignifikancia-szinthez tartozó kritikus érték). Ha el kell vetnünk, akkor van változás (éghajlatváltozás).

\section{Kétdimenziós eset: az SPTI index}

A következőkben összegezve ismertetjük a csapadék- és hőmérsékleti idősorok együttes vizsgálata során végzett kutatásunk módszertanát (Szentimrey et al., 2014). Jelen tanulmányban a legegyszerübb esetet mutatjuk be, azaz az évi csapadékösszeg és átlaghőmérsékleti idősorok együttes vizsgálatát. Természetesen a módszer általánosan is megfogalmazható (Szentimrey 1999), és kutatásaink kiterjednek magasabb dimenziójú vektorok extrémumainak vizsgálatára is. Ilyen lehetőség például a négy évszak csapadékösszeg- és hőmérsékleti sorainak együttes vizsgálata, ez esetben tehát 8 dimenziós vektorokra definiált normákat számítunk.

Legyen az évi csapadékösszeg: $X_{1}(t) \in \Gamma(p, \lambda) \quad(\mathrm{t}=1, \ldots, \mathrm{n})$

Ekkor a transzformáció:

$Z_{1}(t)=\Phi^{-1}\left(G\left(X_{1}(t)\right)\right) \in N(0,1) \quad(\mathrm{t}=1, \ldots, \mathrm{n})$,

ahol $G(x)$ jelöli a $\Gamma(p, \lambda)$ eloszlásfüggvényét és $\Phi^{-1}$ a standard normális eloszlásfüggvény inverze. $Z_{1}(t)$ a jól ismert SPI ${ }^{1}$ (WMO, 2012).

Legyen az évi középhőmérséklet:

$X_{2}(t) \in N\left(m, \sigma^{2}\right) \quad(\mathrm{t}=1, \ldots, \mathrm{n})$.

Ekkor a transzformáció:

$Z_{2}(t)=\Phi^{-1}\left(F\left(X_{2}(t)\right)\right)=\frac{X_{2}(t)-m}{\sigma} \in N(0,1) \quad(\mathrm{t}=1, \ldots, \mathrm{n})$,

ahol $F(x)$ jelöli a $N\left(m, \sigma^{2}\right)$ eloszlásfüggvényét. $Z_{2}(t)$-t nevezzük STI ${ }^{2}$-nek.

Végül a két változóra együttesen definiáljuk SPTI-t:

$\mathbf{Z}(\mathrm{t})=\left[Z_{1}(\mathrm{t}), Z_{2}(\mathrm{t})\right]^{T}$,

$\|\mathbf{Z}(\mathrm{t})\|_{\mathbf{R}^{-1}}^{2}=\mathbf{Z}(\mathrm{t})^{\mathrm{T}} \mathbf{R}^{-1} \mathbf{Z}(\mathrm{t})=\frac{1}{1-r^{2}}\left(Z_{1}^{2}(\mathrm{t})+Z_{2}^{2}(\mathrm{t})-2 \mathrm{r} Z_{1}(\mathrm{t}) Z_{2}(\mathrm{t})\right)$,

ahol $\mathbf{R}^{-1}$ a korreláció mátrix inverze, $\mathrm{r}=\operatorname{corr}\left(Z_{1}, Z_{2}\right)$.

Így SPTI felírható $\|\mathbf{Z}(\mathrm{t})\|_{\mathbf{R}^{-1}}$ alakban.

Tehát az elemzés során a fentebb definiált SPTI sorokat vizsgáljuk mind országos átlagban, mind pedig a rácsponti értékekre.

\footnotetext{
${ }^{1}$ Standardized Precipitation Index: Standardizált csapadék index

${ }^{2}$ Standardized Temperature Index: Standardizált hőmérsékleti index
} 


\section{Eredmények}

\section{Egydimenziós szélsőségek}

Amennyiben az átlaghőmérséklet és csapadékösszeg idősorokat önmagukban vizsgáljuk (4. ábra), a szélsőséges évek az idősor maximumaihoz és minimumához tartozó évek lesznek. Míg a leghidegebb év az 1940-es év volt, addig a legmelegebb évnek a tavalyi - 2019-es - év adódik. A legcsapadékosabb a 2010-es év volt, és az ezt közvetlenül követő 2011-es év bizonyult a legszárazabbnak.
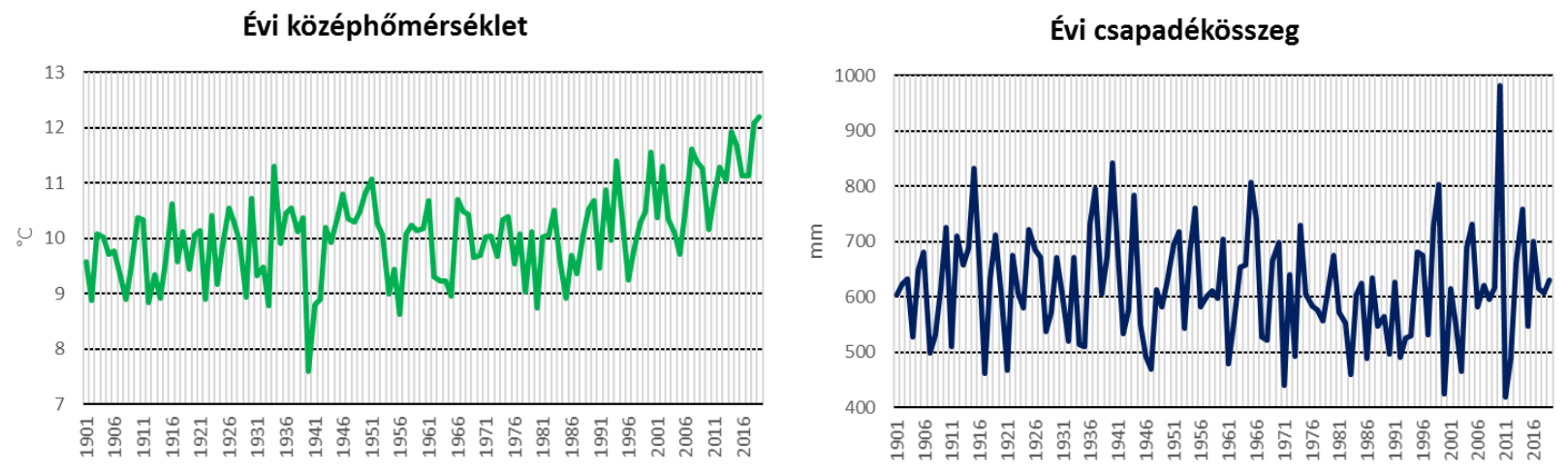

4. ábra: Évi középhőmérsékletek $\left({ }^{\circ} \mathrm{C}\right)$ és az évi csapadékösszegek $(\mathrm{mm})$ országos átlagaiból képzett idősorok, 1901-2019.

\section{SPTI országos átlag}

A következőkben ismertetjük az SPTI értékek országos átlagait. Ehhez az 1233 magyarországi rácspontra (3. ábra) interpolált napi csapadék- és hőmérséklet-adatokat használtuk fel, minden pontra meghatároztuk az SPI és az STI értékeket, majd az ezek alapján számolt SPTI értékek alapján határoztuk meg az ország teljes területére vonatkozó értékeket. Ahhoz, hogy a komponensek azonos eloszlására vonatkozó nullhipotézist elfogadjuk-e, meg kell adni az adott szignifikancia szinthez tartozó kritikus értéket. Jelen esetben 0,1-es szignifikancia szinten határoztunk meg bizonyos kritikus értékeket.

A kritikus értékek az alábbiak alapján értelmezhetők:

- Bármelyik $\operatorname{SPTI}(t)(t=1,2, \ldots, n)$ statisztika, 0,1 valószínüséggel érheti el a $c r 1$ kritikus értéket, tehát ez várhatóan a statisztikák $10 \%$-ánál következik be.

- Az $\operatorname{SPTI}(t)(t=1,2, \ldots, n)$ statisztikák maximuma, legfeljebb 0,1 valószínüséggel érheti el a $c r 2$ kritikus értéket.

A fenti kritikus értékek a jelen esetben $\mathbf{C r 1 = 2 , 1 5}$ és $\mathbf{C r 2 = 3 , 7 2}$. 


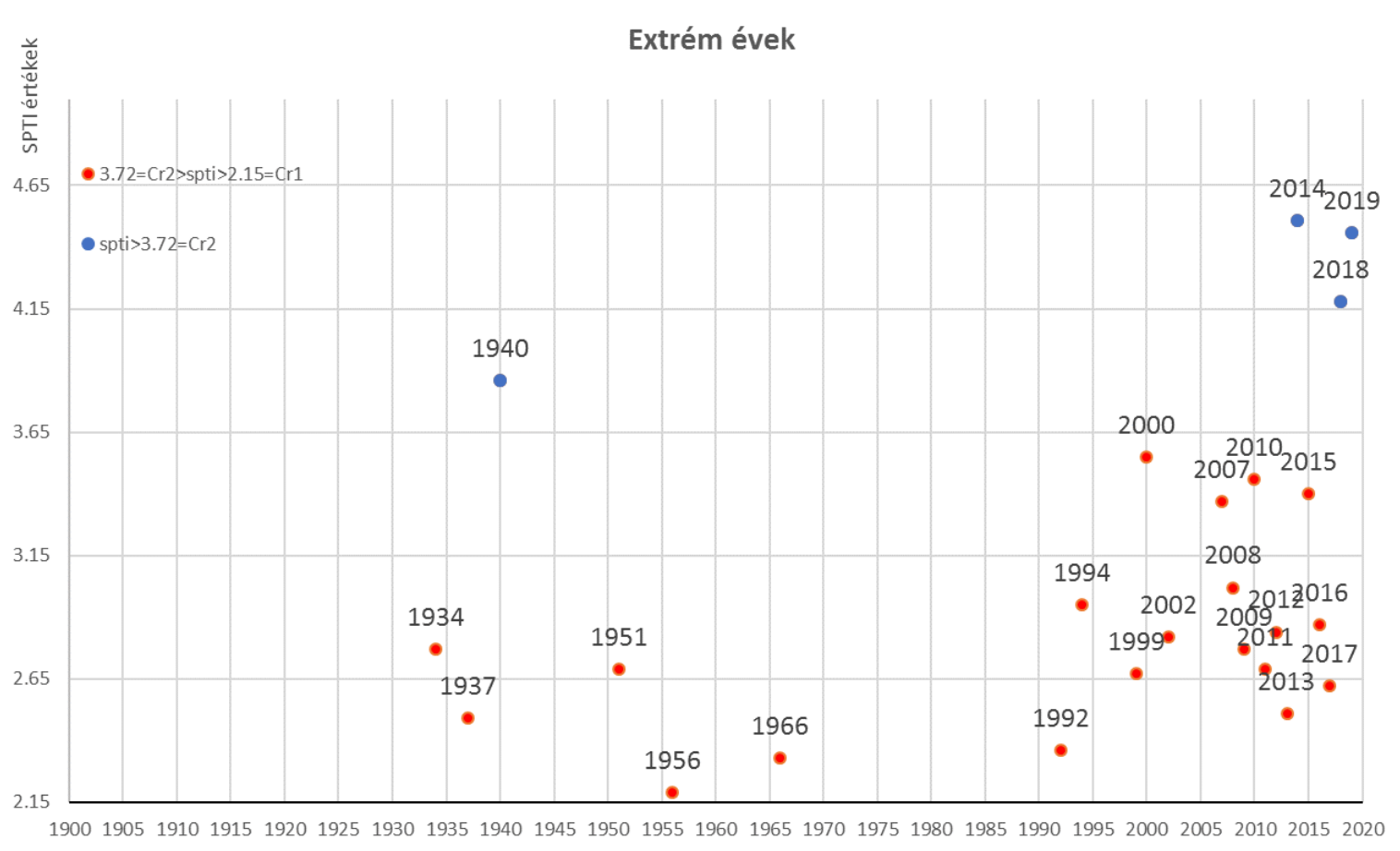

5. ábra: A cr1=2,15 és cr2=3,72 kritikus értékeket meghaladó SPTI értékek, 1901-2019.

A kritikus értékek meghatározásánál feltételeztük a transzformált komponensek együttes normalitását. A $\|\mathbf{Z}(t)\|_{\mathbf{R}^{-1}}^{2}$ két korrelálatlan standard normális változó négyzetösszege, megközelítően 2 szabadsági fokú $\chi^{2}$ eloszlású. Tehát a $\|\mathbf{Z}(t)\|_{\mathbf{R}^{-1}}$ norma 2 szabadsági fokú $\chi$ eloszlású. Az 5. ábrán csak azokat az éveket tüntettük fel, ahol a cr1 kritikus érték feletti SPTI-k adódtak: pirossal azok az évek vannak feltüntetve, melyek még nem érik el a cr2 kritikus értéket, míg kék színnel a szigorúbb cr2-t is meghaladó értékek szerepelnek. Ahogyan az a grafikonon is jól látszik, meglehetősen sok SPTI érték haladja meg a cr1-et, és

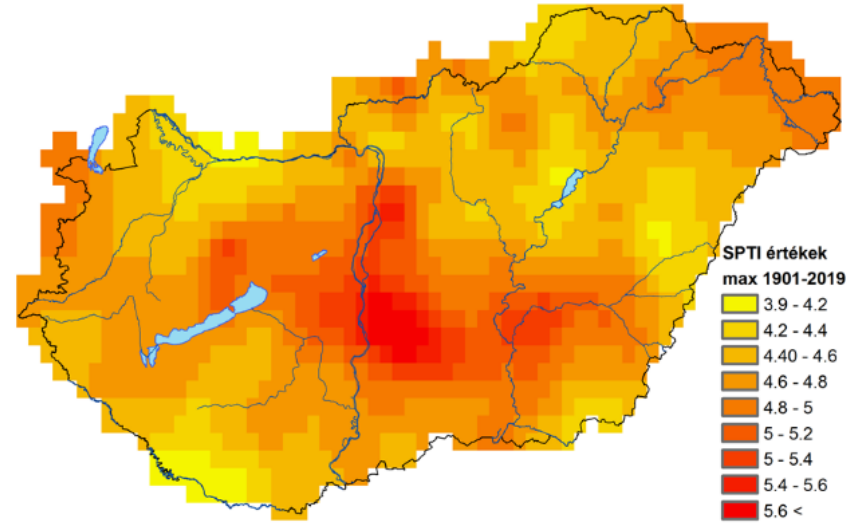

6. ábra: Az SPTI értékek maximuma, 1901-2019. leginkább az elmúlt két évtizedben jelentkezik sok szélsőséges év. A cr2 kritikus értéket négy év haladja meg, az 1940-es hideg csapadékos év, 2018 és 2019 (vagyis a két legmelegebb év átlagos csapadékkal), végül a legnagyobb a normája a 2014-es évnek, ami egy nagyon csapadékos (sorrendben a 9. 1901-től tekintve a csapadék sorokat) és igen forró (sorrendben a 3. legmelegebb az elmúlt 119 évben) év volt. Tehát elmondhatjuk, hogy együtt vizsgálva a csapadékösszeg és az átlaghőmérséklet országos átlag sorokat, a nagyon meleg csapadékos 2014es év a legszokatlanabb az elmúlt 119 év adatai alapján. Azt is elmondhatjuk, hogy az azonos eloszlásra vonatkozó nullhipotézist el kell vetnünk, tehát együttesen vizsgálva a két meteorológiai elemet van éghajlatváltozás Magyarországon. 


\section{SPTI rácspontokban}

Tekintve, hogy akár az átlaghőmérséklet idősorokat vizsgáljuk akár a csapadékösszeget, nem minden egyes pontban ugyanaz a szélsőséges év, mint az országos átlag alapján kapott extrémum, megvizsgáljuk, mely területeken van Magyarországon éghajlatváltozás, és meghatározzuk azt is, hogy mely év volt extrém. Ehhez kiszámítottuk az SPTI értékeket az összes 1233 magyarországi rácspontra, és megkerestük, hogy melyik évhez tartozik a maximális SPTI érték. A 6. ábrán mutatjuk be a maximális SPTI értékeket, a térképről jól látszik, hogy ezek a maximumok minden egyes pontban meghaladják a cr2-t, tehát minden egyes rácspontra igaz az, amit az országos átlag esetén is kaptunk, azaz Magyarország teljes területén van éghajlatváltozás a csapadék- és hőmérsékleti

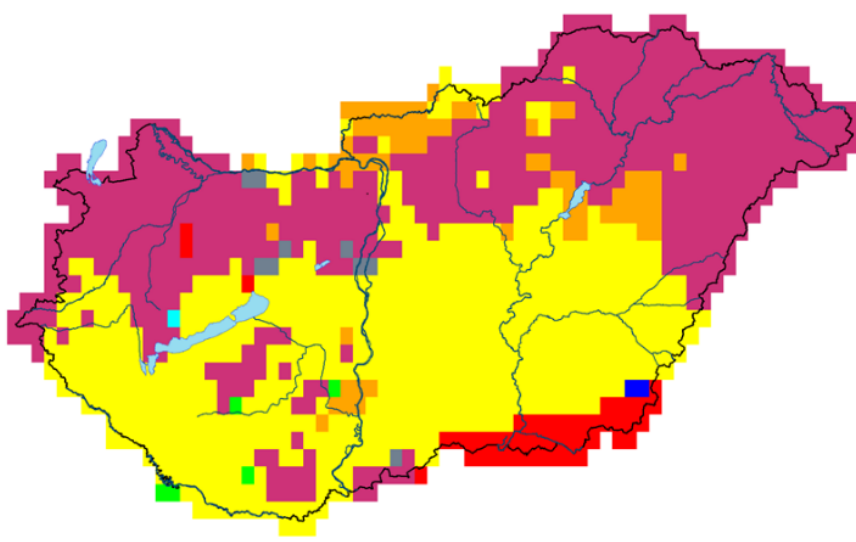

7. ábra: Az SPTI értékek maximumához tartozó év.

\begin{tabular}{|c|c|}
\hline 1940 & 1999 \\
\hline 2010 & 2011 \\
\hline 2018 & 2019 \\
\hline
\end{tabular}
sorokat együtt vizsgálva. A 7. ábra mutatja be, hogy melyik évhez tartozik a maximális SPTI érték. A legnagyobb területen a nagyon csapadékos és forró 2014-es év jelenik meg, de nagy kiterjedésben - föként az ország északi területein - az átlagos csapadékú, legforróbb 2019-es évhez tartozik ez az extrémum. E két éven kívül még egyes helyeken a leghidegebb és csapadékos 1940-es év; az 1999-es nagyon csapadékos és meleg év; a 2000-es második legszárazabb, de meleg év; a 2010-es átlagos hőmérsékletü, de legcsapadékosabb év; a 2011-es legszárazabb és meleg év, valamint a 2018-as második legmelegebb és átlagos csapadékú év jelentkezik.

\section{Összegzés}

A többdimenziós éghajlati idősorok extrémumainak vizsgálata tehát egyértelmüen többlet információt ad az egydimenziós vizsgálatokhoz képest, ezzel kiegészíti azokat. Míg az egydimenziós esetben a hőmérsékletváltozás Magyarország teljes területén szignifikáns, és egyértelmủ melegedés tapasztalható az ország minden pontjában, addig csapadék esetén ez nem mondható el: csak foltokban tapasztalunk szignifikáns változást, nevezetesen a nyugati országrészen csökkenést, az Alföld északi területein viszont ezzel ellentétes irányú változást detektálhatunk. Ugyanakkor ez a tanulmány rámutat arra, hogy a két elemet együttesen tekintve kimutatható az éghajlatváltozás minden egyes pontban. Habár az itt tárgyalt SPTI mutató a legegyszerübb példa a többdimenziós éghajlati idősorok együttes vizsgálatára, ez alapján könnyen alkalmazható a módszer több változó esetén is. 


\section{Köszönetnyilvánítás}

Az Innovációs és Technológiai Minisztérium ÚNKP-20-3 kódszámú Új Nemzeti Kiválóság Programjának a Nemzeti Kutatási, Fejlesztési és Innovációs Alapból finanszírozott szakmai támogatásával készült.

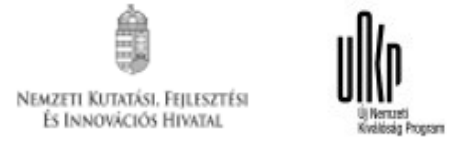

Az SPTI ábrákat Szentes Olivér készítette.

\section{Hivatkozások}

Izsák, B., Szentimrey, T., 2020: To what extent does the detection of climate change in Hungary depend on the choice of statistical methods? Int J Geomath, 11: 17 https://doi.org/10.1007/s13137$\underline{020-00154-\mathrm{y}}$

Szentimrey, T., 1999: Többdimenziós éghajlati idősorok “extrémumainak" vizsgálata, Meteorológiai Tudományos Napok'99 Kiadványa, pp. 77-88.

Szentimrey, T., 2014: Manual of homogenization software MASHv3.03. In. Hungarian Meteorological Service, Budapest, Hungary

Szentimrey, T., Bihari, Z., 2014: Manual of interpolation software MISHv1.03. p. 89. Hungarian Meteorological Service, Budapest, Hungary

Szentimrey T., Lakatos M., Bihari Z., 2014: Joint examination of climate variables, Standardized Precipitation and Temperature Index (SPTI). EMS Annual Meeting Abstracts. Vol. 11, EMS2014443, EMS \& ECAC 2014, 5-10 October, 2014. Prague, Czech Republic. https://meetingorganizer.copernicus.org/EMS2014/EMS2014-443.pdf

WMO, 2012: Standardized Precipitation Index User Guide. WMO-No. 1090. 24p. ISBN 978-92-6311090-9 https://library.wmo.int/index.php?lvl=notice display\&id=13682\#.X41JJ-28qUk

\section{ORCID}

Izsák B. (i) https://orcid.org/0000-0003-1323-5389

Pongrácz R. (D) https://orcid.org/0000-0001-7591-7989

Lakatos M. (D) https://orcid.org/0000-0002-3705-0306 